\title{
E- Complaining: Analysis of Lodging Customers' e-Complaints from a Turkish Internet Website
}

\author{
Ferika Özer Sarı ${ }^{1}$ Özlem Alikılıç ${ }^{2}$ Ferah Onat ${ }^{3}$ \\ ${ }^{1}$ Yasar University, Turkey, ferika.ozersari@yasar.edu.tr \\ ${ }^{2}$ Yasar University, Turkey, ozlem.alikilic@yasar.edu.tr \\ ${ }^{3}$ Yasar University, Turkey, ferah.onat@yasar.edu.tr
}

\begin{abstract}
E-complaints are important feedback mechanisms to monitor and respond consumer complaints on a real time basis. Aim of this research is to analyze the content of e-complaints about Turkish lodging sector and to detect the resolution of them by the companies. In this regard, the data obtained from one of the most popular Turkish e-complaint sites "Sikayetvar .com". Content analysis method is used to classify complaints according to predetermined 15 problem categories and the responses of the hotels were tracked. Findings revealed that majority of e-complaints were related to the main service responsibilities of hotels such as food and beverage services, guestrooms, public areas and courtesy of employees.
\end{abstract}

Keywords: E-Complaints, E-CRM, Turkish Lodging Sector

\section{Introduction}

Consumer complaint is important from the perspectives of customer relations management, positive word of mouth marketing and social welfare. Consumer complaints constitute an important feedback mechanism for companies to monitor consumer satisfaction from their products and services. In his study,
Dolinsky (1994) admitted that complaints may provide greatest value to the companies which are especially in service industry. Best and Andreasen have also (1997) contributed that services cause greater dissatisfaction among customers than those of goods. E-complaint forums and the web sites yield many opportunities for the companies to monitor complaints on a real time basis where services are discussed, to inform their customers that company resolves the subject in question, as well. In the broad context of e-services, e-tourism specifies the competitive power of the company by taking advantage of internet for interacting with all parties concerned and it includes all business functions as well as e-planning, e-management for all subsectors of tourism industry (for example: transport, leisure, accommodation, travel agencies and tour operators, public organizations) (Cooper et al., 2008, 627). Accordingly, electronic customer relationship management (e-CRM) in the context of internet distribution and marketing in the tourism realm, is a business strategy underpinned by Web technologies and it allows travel organizations to incorporate customers into more personalized interactive relationships that are advantageous for both parties (Starkov, 2009). As noted by Harrison-Walker (2001: 402), complaint 
sites may simply be easier for consumers to identify and access than contacting directly with the company.

In 2012, Turkey's most popular complaint site (established in 2001) "Sikayetvar.com", boasted 75.000 unique visitors per day and 2.500 consumer entries per day (Sayhan, 2012). Such numbers suggest a growing need for lodging companies to take e- complaints into account and assign them more priority.

\section{Theoretical Background}

Singh (1988) has contributed a typology of consumer complaint responses. He classified complaining behavior as either third party (complaints lodged with some independent organization), voice (complaints lodged with the faltering company), or private (complaints lodged with family or friends), all three of which are present in e-complaints (Tyrrell and Woods, 2004: 185). "Sikayetvar.com" is a good example of a third party that receives and disseminates e-complaints. Turkish complaint site allows all contributors to post a company's overt name, responses from company, and even it provides an industry classification.

In addition to Singh's (1988) seminal contribution to the field, most of the research relating e-complaints has been based on the study developed by Harrison Walker (2001), such as the work by Changuk Lee and Hu (2004), Tyrrell and Woods (2004).

\section{Methodology and Findings}

Current research has been carried out because of the reality that the studies dealing with e- complaints in Turkey's tourism industry are very limited. This exploratory study attempts to provide some insights about e-complaints by analyzing lodging customers' online complaints that were captured from a Turkish complaint web site. Main purposes of this research are; to analyze the content of e- complaints that were filed in to a Turkish complaint web site based on lodging sector and to detect the organizational responses and feed backs. In this regard, following research questions (RQ) were developed: $\boldsymbol{R Q 1}$. What is the nature and typology of e-complaints that address lodging sector? $\boldsymbol{R Q 2}$. How analytical were the organizations' attempts in terms of resolving problems? $\boldsymbol{R Q 3}$. Is there any relationship between gender and the complaint typology?

The data are drawn from the most popular Turkish online complaint site named "Sikayetvar.com". This site was selected because of its popularity, its wide experience and its professionally designed structure in terms of the data obtained. 12 months of data were analyzed from aforementioned web site. A total of 397 filed complaints were transferred into a single document as the data for content analysis. The dataset were analyzed according to following predetermined problem categories which specify the lodging companies:

01-Employee rudeness; 02- Employee incompetence; 03- Misinformation from employees; 04- Refund problem; 05Misleading advertising; 06- Low service quality; 07- Promised but never provided service; 08- Unexpected fees added to the bill; 09- Unresponsiveness to requests; 10- Guestroom based problems; 11- Catering based problems; 12- Noise; 13General cleanliness problem; 14- Safety and Security Problems; 15- Other Complaints. The first four categories were adapted from Harrison- Walker (2001), categories from 05 to 09 were adapted from Changuk Lee \& Hu (2004) and last six categories are newly created by the authors. The data were analyzed by using SPSS statistical analysis program and findings are below. 
$R Q 1$. What is the nature and typology of e-complaints that address lodging sector?

The text was examined thoroughly within the framework of predetermined problem categories. At the end of this study, researchers have derived 1.352 single problems from 397 individual customer complaint files. Table 1 depicts that the top problem category was catering based problems with $\mathrm{N}=204, \% 15$, second category was guestroom based problems with $\mathrm{N}=180, \% 13,3$ and the third was general cleanliness problems with $\mathrm{N}=177, \% 13$. The least reason for customer complaint was noise with $\mathrm{N}=$ $5, \% 0,4$.

Table 1.Frequency of problem categories

\begin{tabular}{|lcc|}
\hline $\begin{array}{c}\text { Problem } \\
\text { Category }\end{array}$ & $\begin{array}{c}\text { Number of } \\
\text { Problems }\end{array}$ & $\begin{array}{c}\text { Percent } \\
\text { (\%) }\end{array}$ \\
\hline Catering problem & $\mathbf{2 0 4}$ & $\mathbf{1 5}$ \\
Guestroom problem & 180 & 13,3 \\
General cleanliness & 177 & 13 \\
Employee rudeness & 115 & 8,5 \\
Low quality service & 107 & 8 \\
Misleading adv. & 88 & 6,5 \\
Emp. incompetence & 84 & 6,2 \\
Service not provided & 76 & 5,6 \\
Unresponsiveness & 73 & 5,3 \\
Safety and security & 69 & 5,1 \\
problem & 57 & 4,3 \\
Other Complaints & 48 & 3,5 \\
Refund problem & 39 & 3 \\
Misinformation & 30 & 2,3 \\
Added fees to bill & $\mathbf{5}$ & $\mathbf{0 , 4}$ \\
Noise & 1.352 & 100 \\
\hline TOTAL & & \\
\hline
\end{tabular}

$\boldsymbol{R Q 2}$. How analytical were the organizations' attempts in terms of resolving problems?
Table 2 indicates that many lodging companies have not taken notice of ecomplaints.

Table 2.State of complaint resolutions

\begin{tabular}{|cccc|}
\hline \multicolumn{3}{|c}{ Complaints Resolved } & $(\mathbf{N = 3 9 7 )}$ \\
\hline Positive & Neutral & Negative & Total \\
\hline 8 & 3 & 2 & 13 \\
\hline
\end{tabular}

On the web site, only 13 of 397 filed complaints were resolved by the hotel organizations. In contrast with the organizations, number of registered complaints $(\mathrm{N}=397)$ show that lodging customers see the effectiveness and importance of electronic media.

$\boldsymbol{R Q 3 . ~ I s ~ t h e r e ~ a n y ~ r e l a t i o n s h i p ~ b e t w e e n ~}$ gender and the problem categories?

In order to analyze if there is a dependency between gender and problem categories of customer complaints, the chi square test of independence was conducted. The chi square tests are used when the aim is to understand if there is a dependency between two categorical variables or if they're independent of each other (Sekaran, 1992, 266). Results have shown that there is no statistically significant relationship between gender and the problem categories. On the other hand, it's been revealed that the majority of lodging customers who registered their complaints to the web site are males with a percentage of 61 (Table 3 ).

Table 3.Gender Status

\begin{tabular}{|ccc|}
\hline Gender & Frequency & Percent (\%) \\
\hline$M$ & 242 & 61 \\
$F$ & 155 & 39 \\
\hline Total & 397 & 100 \\
\hline
\end{tabular}

Additionally, test results have revealed that there are highly significant 
associations between the problem categories that are shown in Table 4.

Table 4. Results of Chi square Independence Test

\begin{tabular}{|lc|}
\hline Crosstabulation & $\begin{array}{c}\text { Asymp. Sig. } \\
\text { (2-sided) }\end{array}$ \\
\hline $\begin{array}{l}\text { General Cleanliness / } \\
\text { Guestroom Problems }\end{array}$ & $0,017^{*}$ \\
G.Cleanliness / Catering P. & $0,005^{*}$ \\
G.Cleanliness / & \\
Unresponsiveness & $0,006^{*}$ \\
Guestroom P. / Catering P. & $0,012^{*}$ \\
Misinfo. from Emp / & \\
Catering Problems & $0,001^{*}$ \\
\hline$*$ p $<0,05$ & \\
\hline
\end{tabular}

As a remarkable finding of the study we see that there is a strong dependency between "General Cleanliness Problems" and in order of "Catering based Problems" (p: 0,005), "Unresponsiveness to requests" (p: 0,006) and "Guestroom based Problems" (p: 0,017). For interpretation of this finding, it can be said that the lodging customers having general cleanliness problems also had problems with food and beverage services, problems with guestrooms and problems with unresponsive staff of hotel. Similarly, it's been found that there is a dependency between "Catering based Problems" and "Guestroom based Problems" (p: 0,012) as well as "Misinformation from Employees" (p: 0,001).

\section{Conclusion}

This study shows that the most of Turkish lodging companies are still unaware of importance of resolving complaints on an "e" basis. However, many researchers suggest that both customer retention and loyalty are enhanced when complaints are handled well (Tyrrell and Woods, 2004; Singh and Wilkes, 1996). Findings of current research show that majority of Turkish lodging customers' e-complaints are related to the main service responsibilities of hotels such as food and beverage services, guestrooms, public areas, hospitality and courtesy of employees. In this regard, lodging companies should integrate themselves into online platforms and keep track of these platforms for gathering information but in a more strategic and professional manner. Customers may decide not to purchase the service again or they can accelerate word of mouth behavior (i.e.; warn family and friends not to choose the brand or service) which can be costly to the organization. Lodging companies should monitor the virtual communities, and should be aware of how their organization is being discussed in online platforms. They should also be ready to become an active part of the conversations by maintaining their involvement with others.

Merely monitoring the complaints will not provide an organization with power of information. Yet, it is evident that those with power continually drive themselves to not only stay updated in the industry, but they also seek leading the lodging industry in a responsive manner. Past researches indicate that reading ecomplaints provide useful information as a strategic management tool for lodging companies.

On the other hand, without knowledge of the sources of complaints, companies will be unable to change its procedures and to take corrective actions. From a social welfare perspective, it also becomes important to attempt for resolving consumer complaints. Such an understanding is important for the future of Turkish lodging sector. 


\section{Limitations of Study and Recommendations for Future Research}

Currently, there exists very little research about e-complaints in Turkey, therefore the authors' future research could be an expansion of this study. The sample could be broadened and researchers may continue to explore e-complaints that address other industries and compare them with each other.

\section{References}

[1] Best, A. and Andreasen, A.R, "Consumer Response to Unsatisfactory Purchases: A Survey of Perceiving Defects, Voicing Complaints, and Obtaining Redress", Law \& Society Review, V.11, N.4, pp. 701-742, 1977.

[2] Cooper, C., Fletcher, J., Fyall, A., Gilbert, D. \& S. Wanhill, Tourism Principles and Practice, 4th. Edition, Harlow: Pearson Education Limited, 2008.

[3] Dolinsky, A.L., "A Consumer Complaint Framework with Resulting Strategies: An Application to Higher Education", Journal of Services Marketing, Vol. 8 Iss: 3, pp.27 - 39, 1994.

[4] Harrison- Walker L. J., "E- Complaining: A Content Analysis of an Internet Complaint Forum", Journal of Services Marketing, Vol. 15 Iss: 5, pp. 397-412, 2001.
[5] Lee C. C. and C. Hu, "Analyzing Hotel Customers' E- Complaints from an Internet Complaint Forum", Journal of Travel \& Tourism Marketing, Vol. 17: 2-3, pp. 167- 181, 2004.

[6] Sayhan, N. (2012). Responsible Manager of Şikayetvar.com Web site, Telephone Interview and Emailing Records, (Nov 08, 2012; Nov 21, 2012)

[7] Sekaran U., Research Methods for Business: A Skill- Building Approach, John Wiley \&Sons Inc., Canada, 1992.

[8] Singh, J., "Consumer Complaint Intentions and Behavior: Definitional and Taxonomical Issues", Journal of Marketing, 59, (1), pp.93-107, 1988.

[9] Singh, J. and Wilkes, R.E., "When Consumers Complain: A Path Analysis of the Key Antecedents of Consumer Complaint Response Estimates", Journal of the Academy of Marketing Science, 24, (1), pp.350365, 1996.

[10] Starkov M., "Is e-CRM in Hospitality a Database Management or a Business Strategy to Engage the Customer?", 2009 , http://www.hebsdigital.com (Accessed: 15.11.2012)

[11]Tyrell, B. and Woods, R., "EComplaints: Lessons to be Learned from the Service Recovery Literature", Journal of Travel \& Tourism Marketing, 17: 2-3, pp.183$190,2004$. 